\title{
Association of Serum Uric Acid and Serum Calcium with Preeclampsia and Eclampsia
}

\author{
Rekha Wadhwani $^{1} \odot$ Kanchan N Verma $^{2} \odot$, Neetu Ahirwar ${ }^{3} \odot$
}

\begin{abstract}
Aim and objective: To determine the correlation of serum uric acid and serum calcium with the severity of preeclampsia and eclampsia. Materials and methods: The present case-control study has been carried out for a period of 1 year from March 2018 to February 2019 after institutional ethical clearance. The sample size of the study was 150 cases and 150 controls. This was a case-control study. Cases were admitted patients with preeclampsia or eclampsia. Controls were normotensive pregnant women. On admission, after informed consent, venous serum samples were collected prior to their commencement of intravenous therapy and magnesium sulfate therapy. Blood samples obtained on admission were sent for serum calcium and serum uric acid level estimation, and then, the results were analyzed.

Result: The mean serum uric acid among cases was $6.98 \pm 1.85 \mathrm{mg} / \mathrm{dL}$, whereas in controls, it was $4.55 \pm 1.38 \mathrm{mg} / \mathrm{dL}$; similarly, the mean serum calcium among cases and controls was $8.44 \pm 1.1$ and $9.87 \pm 0.69$, respectively. Test of significance observed statistically highly significant difference in mean serum uric acid and serum calcium between cases and controls $(p<0.01)$. The present study observed a significantly higher occurrence of cerebrovascular accident (CVA), and postpartum hemorrhage (PPH) among cases with serum uric acid level greater than $6.2 \mathrm{mg} / \mathrm{dL}$ as compared to cases with serum uric acid level less than $6.2 \mathrm{mg} / \mathrm{dL}(p<0.05)$. The present study observed that CVA was significantly higher in cases with serum calcium level less than $9 \mathrm{mg} / \mathrm{dL}(p<0.05)$. The occurrence of deaths due to pulmonary embolism (PE), pulmonary edema, acute respiratory distress syndrome (ARDS), and multiple organ dysfunction syndrome (MODS) was higher in patients with raised serum uric acid level. Conclusion: The present study found that elevated serum uric acid level could be used as a biochemical marker for preeclampsia and eclampsia. Calcium supplement may help in the reduction of incidence of preeclampsia and eclampsia in country especially where nutrition is poor.

Keywords: Case, Control, Eclampsia, Preeclampsia, Serum calcium, Serum uric acid.

Journal of South Asian Federation of Obstetrics and Gynaecology (2021): 10.5005/jp-journals-10006-1910
\end{abstract}

\section{INTRODUCTION}

Hypertensive disorders in pregnancy (HDP) are one of the deadly triads, along with hemorrhage and infection, and are responsible for $10.8 \%$ of maternal mortality in India. In preeclampsia and eclampsia, significant changes are seen in various biochemical parameters like uric acid and serum calcium. Hyperuricemia due to oxidative stress is associated with deleterious effects on endothelial dysfunction, oxidative metabolism, platelet adhesiveness, and aggregation. ${ }^{2}$ Hence, elevated serum uric acid is highly predictive of increased risk of adverse maternal and fetal outcomes. ${ }^{3}$ Blood calcium has a relaxant effect on the blood vessels of pregnant women. ${ }^{4}$ The significant reduction in serum calcium and magnesium is found in preeclamptic mothers. ${ }^{5,6}$ serum uric acid levels increase very early at 10 th week of gestation in patients who later develop preeclampsia. ${ }^{7}$ The understanding of the underlying factors that explain the pathogenesis of preeclampsia and eclampsia and the early identification of the patients at risk of the disease will help in the development of preventative or early therapeutic interventions, aimed to reduce not only the associated morbidity and mortality during pregnancy but also the long-term severe problems that preeclampsia may produce or is associated with. Hence, this study was undertaken to evaluate the role of calcium and uric acid in the pathogenesis of preeclampsia and eclampsia and thus to find measures before deleterious effect develops. The aim and objective of this study were to determine the correlation of serum uric acid and serum calcium with the severity of preeclampsia and eclampsia.
${ }^{1-3}$ Department of Obstetrics and Gynaecology, Gandhi Medical College, Bhopal, Madhya Pradesh, India

Corresponding Author: Neetu Ahirwar, Department of Obstetrics and Gynaecology, Gandhi Medical College, Bhopal, Madhya Pradesh, India, Phone: +91 9584203942, e-mail: neetuahirwarbharang@gmail.com

How to cite this article: Wadhwani R, Verma KN, Ahirwar N. Association of Serum Uric Acid and Serum Calcium with Preeclampsia and Eclampsia. J South Asian Feder Obst Gynae 2021;13(3):110-113.

Source of support: Nil

Conflict of interest: None

\section{Materials and Methods}

This case-control study has been carried out in the Department of Obstetrics and Gynecology, Gandhi Medical College, Bhopal, for a period of 1 year from March 2018 to February 2019. The study was carried out in accordance with the Declaration of Helsinki's Principle; 150 cases and 150 controls were enrolled for the study. An institutional ethical clearance was taken for the study from the Institutional Ethics Committee of Gandhi Medical College, Bhopal, Letter No 3773-75/MC/EC/2018, Bhopal, Date 30/1/2018, and all patients in this study signed an informed consent. Cases were admitted patients with preeclampsia or eclampsia. Controls were normotensive pregnant women. Inclusion criteria for cases were preeclampsia or eclampsia condition with a singleton pregnancy. Exclusion criteria for cases were gestational age less than 20 weeks, multiple pregnancy, chronic hypertension, and other maternal 
high risk factors like diabetes mellitus, hypothyroidism, and renal disease. On admission, venous serum samples were collected prior to their commencement of magnesium sulfate therapy and sent for serum calcium and serum uric acid level estimation, and then, the results were analyzed.

\section{RESULt}

The study enrolled 150 patients diagnosed clinically with preeclampsia and eclampsia who were compared with 150 normal subjects. Serum uric acid and serum calcium levels were estimated, analyzed, and compared. The mean age of the cases was found to be $24.9 \pm 7.03$ years, whereas the mean age of the control group was found to be $23.71 \pm 4.41$ years $(p>0.05)$. Test of significance observed no statistical difference in place of residence between the cases and control groups $(p>0.05)$. The parity status of cases and controls in the present study was comparable $(p>0.05)$. The gestational age of the majority of cases $(59.3 \%)$ and controls (49.3\%) was between 28 weeks and 36 weeks followed by 37 and 40 weeks in $30 \%$ of cases and $36 \%$ of controls, respectively. Test of significance observed no statistical difference in the gestation age of cases and controls $(p>0.05)$. The majority of patients among cases, that is, $79.3 \%$, were unbooked, whereas $44.7 \%$ of controls were booked, and the difference in booking status between cases and controls was statistically highly significant $(p<0.01)$. The mean serum uric acid among cases was $6.98 \pm 1.85 \mathrm{mg} / \mathrm{dL}$, whereas in controls, it was $4.55 \pm 1.38 \mathrm{mg} / \mathrm{dL}$; similarly, the mean serum calcium among cases and controls was $8.44 \pm 1.1$ and $9.87 \pm 0.69$, respectively. Test of significance observed statistically highly significant difference in the mean serum uric acid and serum calcium between cases and controls $(p<0.01)$ (Table 1). cerebrovascular accident (CVA) and postpartum hemorrhage (PPH) were seen in 20 and $12.7 \%$ of cases, respectively. The present study observed a significantly higher occurrence of CVA, and PPH among cases with serum uric acid level greater than $6.2 \mathrm{mg} / \mathrm{dL}$ as compared to cases with serum uric acid level less than $6.2 \mathrm{mg} / \mathrm{dL}(p<0.05)$. Serum calcium level was less than 9 in $90 \%$ of patients with CVA and $63.8 \%$ of patients with $\mathrm{PPH}$. The present study observed that CVA was significantly higher in cases with serum calcium level less than $9 \mathrm{mg} / \mathrm{dL}(p<0.05)$ (Tables 2 and 3 ). Though the occurrence of other complications was also higher in patients with reduced serum calcium level, the difference was not statistically significant $(p>0.05)$. Mortality was observed in 11 cases in the present study. The most common cause of mortality was a pulmonary embolism (PE) in $27.3 \%$ of cases and CVA in $27.3 \%$ of cases. Disseminated intravascular coagulation (DIC) was observed in $18.2 \%$ of cases.

Among the cases (27.3\%) in which PE was the cause of death, $66.7 \%$ of cases had serum uric acid level more than $6.2 \mathrm{mg} / \mathrm{dL}$, and among the cases (27.3\%) in which CVA was the cause of death, serum uric acid level was more than $6.2 \mathrm{mg} / \mathrm{dL}$ in $33.3 \%$ of cases. The occurrence of deaths due to PE, pulmonary edema, acute respiratory distress syndrome (ARDS), and multiple organ dysfunction syndrome (MODS) was higher in patients with raised

Table 1: Mean serum uric acid and serum calcium levels between cases and controls

\begin{tabular}{llcccc}
\hline & \multicolumn{2}{c}{ Serum uric acid $(\mathrm{mg} / \mathrm{dL})$} & & \multicolumn{2}{c}{ Serum calcium $(\mathrm{mg} / \mathrm{dL})$} \\
\cline { 2 - 3 } \cline { 5 - 6 } Groups & Range & Mean $\pm S D$ & & Range & Mean $\pm S D$ \\
\hline Cases & $2.9-15$ & $6.98 \pm 1.85$ & $6-11.2$ & $8.44 \pm 1.1$ \\
Controls & $2.5-7.8$ & $4.55 \pm 1.38$ & & $8.1-10.9$ & $9.87 \pm 0.69$ \\
$t$-test & \multicolumn{2}{c}{12.89} & & \multicolumn{2}{c}{13.48} \\
$p$ value & \multicolumn{2}{c}{0.001} & & 0.001 \\
\hline
\end{tabular}

Table 2: Association of maternal complications with serum uric acid levels in cases

\begin{tabular}{|c|c|c|c|c|c|c|c|c|}
\hline \multirow[b]{3}{*}{ Complications } & \multirow{3}{*}{$\begin{array}{l}\text { No. of } \\
\text { cases }\end{array}$} & \multirow[b]{3}{*}{$\%$} & \multicolumn{4}{|c|}{ Serum uric acid } & \multirow[b]{3}{*}{$x^{2}$} & \multirow[b]{3}{*}{$p$ value } \\
\hline & & & \multicolumn{2}{|c|}{$>6.2 \mathrm{mg} / \mathrm{dL}$} & \multicolumn{2}{|c|}{$<6.2 \mathrm{mg} / \mathrm{dL}$} & & \\
\hline & & & $n$ & $\%$ & $n$ & $\%$ & & \\
\hline CVA & 30 & 20 & 25 & 83.3 & 5 & 16.7 & 4.1 & 0.04 \\
\hline $\mathrm{PPH}$ & 19 & 12.7 & 17 & 89.5 & 02 & 10.5 & 4.6 & 0.03 \\
\hline HELLP & 10 & 6.7 & 08 & 80 & 02 & 20 & 0.71 & 0.4 \\
\hline ARF & 08 & 5.3 & 04 & 50 & 04 & 50 & 1.25 & 0.26 \\
\hline Papilledema & 06 & 4 & 04 & 66.7 & 02 & 33.3 & 0.005 & 0.91 \\
\hline Pulmonary edema & 05 & 3.3 & 04 & 80 & 01 & 20 & 0.34 & 0.55 \\
\hline
\end{tabular}

Table 3: Association of maternal complications with serum calcium levels in cases

\begin{tabular}{|c|c|c|c|c|c|c|c|c|}
\hline \multirow[b]{3}{*}{ Complications } & \multirow{3}{*}{$\begin{array}{l}\text { No. of } \\
\text { cases }\end{array}$} & \multirow[b]{3}{*}{$\%$} & \multicolumn{4}{|c|}{ Serum calcium } & \multirow[b]{3}{*}{$x^{2}$} & \multirow[b]{3}{*}{$p$ value } \\
\hline & & & \multicolumn{2}{|c|}{$>9 \mathrm{mg} / \mathrm{dL}$} & \multicolumn{2}{|c|}{$<9 \mathrm{mg} / \mathrm{dL}$} & & \\
\hline & & & $n$ & $\%$ & $n$ & $\%$ & & \\
\hline CVA & 30 & 20 & 03 & 10 & 27 & 90 & 5.3 & 0.02 \\
\hline $\mathrm{PPH}$ & 19 & 12.7 & 07 & 36.8 & 12 & 63.2 & 1.2 & 0.2 \\
\hline HELLP & 10 & 6.7 & 01 & 1 & 09 & 90 & 1.5 & 0.2 \\
\hline ARF & 08 & 5.3 & 02 & 2 & 06 & 75 & 0.01 & 0.9 \\
\hline Papilledema & 06 & 4 & 01 & 16.7 & 05 & 83.3 & 1.5 & 0.2 \\
\hline Pulmonary edema & 05 & 3.3 & 01 & 20 & 04 & 80 & 0.11 & 0.7 \\
\hline
\end{tabular}


Table 4: Maternal mortality among cases and their association with serum uric acid level

\begin{tabular}{|c|c|c|c|c|c|c|c|c|}
\hline \multirow[b]{3}{*}{ Cause of death } & \multirow[b]{3}{*}{ No. } & \multirow[b]{3}{*}{$\%$} & \multicolumn{4}{|c|}{ Serum uric acid } & \multirow[b]{3}{*}{$x^{2}$} & \multirow[b]{3}{*}{$p$ value } \\
\hline & & & \multicolumn{2}{|c|}{$>6.2 \mathrm{mg} / \mathrm{dL}$} & \multicolumn{2}{|c|}{$<6.2 \mathrm{mg} / \mathrm{dL}$} & & \\
\hline & & & $n$ & $\%$ & $n$ & $\%$ & & \\
\hline PE & 03 & 27.3 & 02 & 66.7 & 01 & 33.3 & 0.1 & 0.7 \\
\hline CVA & 03 & 27.3 & 01 & 33.3 & 02 & 66.7 & 0.78 & 0.37 \\
\hline DIC & 02 & 18.2 & 01 & 50 & 01 & 50 & 0.02 & 0.88 \\
\hline Pulmonary edema & 01 & 9.1 & 01 & 100 & 00 & 00 & 0.92 & 0.33 \\
\hline ARDS & 01 & 9.1 & 01 & 100 & 00 & 00 & 0.92 & 0.33 \\
\hline MODS & 01 & 9.1 & 01 & 100 & 00 & 00 & 0.92 & 0.33 \\
\hline
\end{tabular}

Table 5: Maternal mortality among cases and their association with serum calcium

\begin{tabular}{|c|c|c|c|c|c|c|c|c|}
\hline \multirow[b]{3}{*}{ Cause of death } & \multirow[b]{3}{*}{ No. } & \multirow[b]{3}{*}{$\%$} & \multicolumn{4}{|c|}{ Serum calcium } & \multirow[b]{3}{*}{$x^{2}$} & \multirow[b]{3}{*}{$p$ value } \\
\hline & & & \multicolumn{2}{|c|}{$>9 \mathrm{mg} / \mathrm{dL}$} & \multicolumn{2}{|c|}{$<9 \mathrm{mg} / \mathrm{dL}$} & & \\
\hline & & & $n$ & $\%$ & $n$ & $\%$ & & \\
\hline $\mathrm{PE}$ & 03 & 27.3 & 1 & 33.3 & 2 & 66.7 & 2.9 & 0.08 \\
\hline CVA & 03 & 27.3 & 0 & 00 & 3 & 100 & 0.4 & 0.52 \\
\hline DIC & 02 & 18.2 & 1 & 50 & 1 & 50 & 4.95 & 0.02 \\
\hline Pulmonary edema & 01 & 9.1 & 0 & 00 & 1 & 100 & 0.1 & 0.74 \\
\hline ARDS & 01 & 9.1 & 0 & 00 & 1 & 100 & 0.1 & 0.74 \\
\hline MODS & 01 & 9.1 & 0 & 00 & 1 & 100 & 0.1 & 0.74 \\
\hline
\end{tabular}

serum uric acid level, but the difference in the cause of death was not statistically significant $(p>0.05)$. Among the cases $(27.3 \%)$ in which the cause of death was $\mathrm{PE}, 67 \%$ of cases had serum calcium level less than $9 \mathrm{mg} / \mathrm{dL}$. In cases (27.3\%) in which the cause of death was CVA, $100 \%$ of cases had serum calcium level less than $9 \mathrm{mg} / \mathrm{dL}$. Although overall, the present study observed no significant association between the cause of deaths and serum calcium level $(p>0.05)$ (Tables 4 and 5). Still birth was observed in $9.3 \%$ of cases and $2 \%$ of controls, whereas neonatal mortality was observed in $6 \%$ of cases and $2.7 \%$ of controls. The present study observed highly significantly adverse and poor perinatal outcomes among cases as compared to controls $(p<0.01)$.

\section{Discussion}

The mean age of cases in the present study was $24.9 \pm 7.03$ years, whereas in control group, it was $23.71 \pm 4.41$ years, and the age in case and control groups was comparable $(p>0.05)$ as per the study by Kumar et al. (2019). The mean age of controls was $25.34 \pm 4.06$ years, whereas in cases, it was $26.37 \pm 3.87$ years. ${ }^{8}$ In the present study, about 55.3 and $58 \%$ of cases and controls, respectively, were primipara, whereas only $18 \%$ of cases and $12 \%$ of controls were grand multiparas. The parity status of cases and controls in the present study was comparable $(p>0.05)$. Toshniwal et al. (2017) also observed 80 and $72 \%$ of primigravida cases and controls, respectively. ${ }^{9}$ Ephraim et al. (2014) in their study included $55 \%$ of nulliparous females in the control group, $56.7 \%$ in the pregnancy-induced hypertension group, and $60 \%$ in PE group. ${ }^{10}$ In our study, the gestational age of the majority of cases (59.3\%) and controls (49.3\%) was between 28 weeks and 36 weeks followed by 37 weeks and 40 weeks in $30 \%$ of cases and $36 \%$ of controls, respectively. Kumar et al. (2019) also included a majority of patients with gestational age between 37 weeks and 40 weeks in the case as well as control groups. In the present study, the majority of patients among cases, that is, $79.3 \%$, were unbooked, whereas $55.3 \%$ of controls were booked, and the difference in booking status between cases and controls was statistically highly significant $(p<0.01)$. The mean serum uric acid among cases in the present study was $6.98 \pm 1.85 \mathrm{mg} / \mathrm{dL}$, whereas in controls, it was $4.55 \pm 1.38 \mathrm{mg} / \mathrm{dL}$. The observed difference in serum uric acid between cases and controls was statistically highly significant ( $p$ <0.01). Manjreeka et al. (2013) in their study also observed significantly higher mean serum uric acid level in the preeclampsia group, that is, $5.29 \pm 0.84$, as compared to the control group $(3.86 \pm 0.92)^{11}$ found significantly high serum uric acid level $(6.27 \pm 1.37$ vs $4.27 \pm 0.61 \mathrm{mg} / \mathrm{dL})$ in preeclamptic patients compared to their healthy counterparts. A study by showed a significant difference in uric acid level $(p=0.05)$ among both groups. In comparison with the healthy patients, patients with severe preeclampsia and uric acid greater than $6 \mathrm{mg} / \mathrm{dL}$ presented significant differences in relation to fetal complications and maternal complications. A study by Nair et al. in 2017 comprising of 50 cases of preeclampsia found a positive correlation $(r=0.695$ and +0.359 ) between the variables in the study group, and as the systolic blood pressure or diastolic blood pressure increases, the mean serum uric acid concentration also increases. While negative correlation in the control group. ( $r=-0.083$ and -0.095$)$. The elevated serum uric acid level has been postulated due to increased reabsorption and decreased excretion of uric acid in proximal tubules. ${ }^{12}$ Increased serum uric acid in preeclampsia and eclampsia may be secondary to reduced renal clearance of urea and increased xanthine oxidase activity. ${ }^{13}$ In the present study, the mean serum calcium among cases and controls was $8.44 \pm 1.1$ and $9.87 \pm 0.69 \mathrm{mg} / \mathrm{dL}$, respectively, and the observed difference was statistically highly significant $(p<0.01)$. Serum calcium was less than $9 \mathrm{mg} / \mathrm{dL}$ in $73.3 \%$ of cases, whereas it was less than 
$9 \mathrm{mg} / \mathrm{dL}$ in only $15 \%$ of controls. The present study observed a highly statistically significant difference in calcium level between cases and controls $(p<0.01)$. The findings of the present study were similar to the study by Sirajwala et al. (2013); they found a significant association of serum uric acid and serum calcium levels with preeclampsia and also between serum uric acid level and severity of the disease. ${ }^{14}$ Kumar et al. (2019) also observed mean maternal serum calcium to be inversely related to eclampsia as well as preeclampsia. Tuli et al. (2019) found a difference in mean serum calcium was highly significant $(p<0.001)$ when compared between cases and controls. ${ }^{15}$ A study by Kanagal et al. (2014) reported that the serum calcium concentration was significantly lower in the preeclamptic group compared to normotensives $(7.84 \pm 0.87 \mathrm{mg} /$ $\mathrm{dL}$ vs $8.97 \pm 0.69 \mathrm{mg} / \mathrm{dL}, p<0.001)$. Also found that women with preeclampsia had a significantly lower median (interquartile) serum calcium [7.6 (4.0-9.6) vs 8.1 (10.6-14.2), $\mathrm{mg} / \mathrm{dL}, p=0.032$ ] compared to the control group. Our study observed significantly higher occurrence of CVA, and PPH among cases with serum uric acid level greater than $6.2 \mathrm{mg} / \mathrm{dL}$ as compared to cases with serum uric acid level less than $6.2 \mathrm{mg} / \mathrm{dL}(p<0.05)$. Also, CVA was significantly higher in cases with serum calcium levels less than $9 \mathrm{mg} / \mathrm{dL}(p<0.05)$. The present study observed significantly high maternal mortality among cases as compared to controls $(p<0.01)$, that is, in 11 cases and 2 controls. The findings of the present study were similar to the findings of the study by Kumar et al. (2019) in which they observed a significant correlation between maternal hyperuricemia and hypocalcemia with adverse maternal outcomes in women with hypertensive disorders in pregnancy (HDP) as compared to healthy women with normal serum uric acid and serum calcium levels. Maximum cases of maternal mortality in the reference study were observed in the eclampsia group with the highest serum uric acid levels. Sirajwala et al. (2013) in their study concluded that the serum level of uric acid rises as preeclampsia progresses, and serum uric acid level greater than $5.5 \mathrm{mg} / \mathrm{dL}$ is a strong indicator of the disease, whereas a level greater than $7.8 \mathrm{mg} / \mathrm{dL}$ is associated with significant maternal morbidity as well as mortality. ${ }^{14}$ The findings of the present study are similar to the study by Ashgharnia et al. (2017) who reported that hyperuricemia was significantly associated with increased frequency of maternal complications like hepatic dysfunction and adverse and poor maternal outcomes. ${ }^{16}$ Tejal et al. (2014) also concluded that maternal hyperuricemia in HDP was strongly associated with adverse maternal and perinatal outcomes, like an increased risk of APGAR score less than 7 by 6 -fold, intrauterine fetal demise by 20 -fold, intrauterine growth restriction by 4 -fold, and LSCS or operative delivery by 3.4-fold as compared to healthy pregnant women with normal uric acid levels. ${ }^{17}$

\section{Conclusion}

This study found the association of elevated serum uric acid level with preeclampsia and eclampsia, which could be used as a biochemical marker for preeclampsia and eclampsia in antenatal women. Calcium supplementation also may help in the reduction of incidence of preeclampsia and eclampsia, especially in a developing country, where nutrition is poor.

\section{OrCID}

Rekha Wadhwani (10 https://orcid.org/0000-0003-0821-5164 Kanchan N Verma • https://orcid.org/0000-0002-8781-1089

Neetu Ahirwar (ㅇ https://orcid.org/0000-0003-2830-0008

\section{References}

1. Cunningham FG, Leveno KG, Bloom SL, et al. Hypertensive disorders in pregnancy. Williams Obstetrics. 22nd ed. Mc Graw Hill; 2005. p. 761-785.

2. Sibai B, Dekker G, Kupferminc M. Pre-eclampsia. Lancet 2005;365(9461):785-799. DOI: 10.1016/S0140-6736(05)17987-2.

3. Koga K, Osuga $\mathrm{Y}$, Tajima $\mathrm{T}$, et al. Elevated serum soluble fms-like tyrosinekinase 1 (sFlt1) level in women with hydatidiform mole. Fertil Steril 2010;94(1):305-308. DOI: 10.1016/j.fertnstert.2009.02.015.

4. Bdolah Y, Lam C, Rajakumar A, et al. Twin pregnancy and the risk ofpreeclampsia: bigger placenta or relative ischemia? Am J Obstet Gynecol 2008;198(4):428. DOI: 10.1016/j.ajog.2007.10.783.

5. Raijmakers MT, Dechend R, Poston L. Oxidative stress and preeclampsia:rationale for antioxidant clinical trials. Hypertension 2004;44(4):374-380. DOI: 10.1161/01.HYP.0000141085.98320.01.

6. Orhan $\mathrm{H}$, Onderoglu L, Yücel A, et al. Circulating biomarkers of oxidativestress in complicated pregnancies. Arch Gynecol Obstet 2003;267(4):189-195. DOI: 10.1007/s00404-002-0319-2.

7. Roggensack AM, Zhang Y, Davidge ST. Evidence for peroxynitrite formationin the vasculature of women with preeclampsia. Hypertension 1999;33(1):83-89. DOI: 10.1161/01.hyp.33.1.83.

8. Kumar N, Singh AK. Maternal serum uric acid and calcium as predictors On hypertensive disorder of pregnancy: A case control study. Taiwanese Journal of Obstetrics and Gynecology. 2019 Mar 1;58(2):244-50.

9. Toshniwal S, Lamba AR. Serum uric acid as marker of severity of preeclampsia. Int J ReprodContraceptObstetGynececol 2017;6:4915-7 DOI: http://dx.doi.org/10.18203/2320-1770.ijrcog20174999.

10. Ephraim RK, Osakunor DN, Denkyira SW, Eshun H, Amoah S, Anto EO. Serum calcium and magnesium levels in women presenting with preeclampsia and pregnancy-induced hypertension: a case-control study in the Cape Coast metropolis, Ghana. BMC pregnancy and childbirth. 2014 Dec;14(1):390.

11. Manjareeka M, Nanda S. Elevated levels of serum uric acid, creatinine or urea in preeclamptic women. Int J Med Sci Public Health. $2013 \mathrm{Jan}$ 1;2(1):43-7. DOI:10.5455/ijmsph.2013.2.43.47.

12. Nair et al. Estimation of Serum Uric Acid as an Indicator of Severity of Preeclampsia and Perinatal Outcome 2017 JOGI Apr;67(2):109-118. DOI: 10.1007/s13224-016-0933-8. Epub 2016 Sep 9.

13. Kao PC, Shiesh SC, Wu TJ. Serum C-reactive protein as a marker for wellness assessment. Ann Clin Lab Sci 2006;36(2):163-169. DOI: 0091-7370/06/0100-0163.\$1.75.c 2006 by association of clinical scientist,inc.

14. Sirajwala HB, Sharma D, Agravatt AM. A study of serum total calcium and uric acid levels in preeclampsia. Indian Journal of Basic and Applied Medical Research. 2013 Dec;3(1):50-6.

15. Jialal I, Stein D, Balis D, et al. Effect of hydroxymethyl glutaryl coenzyme A reductase inhibitor therapy on highsensitive C-reactive protein levels. Circulation 2001;103(15):1933-1935. DOI: 10.1161/01. cir.103.15.1933.

16. Asgharnia M, Mirblouk F, Kazemi S, Pourmarzi D, Keivani MM, Heirati SF. Maternal serum uric acid level and maternal and neonatal complications in preeclamptic women: A cross-sectional study. International Journal of Reproductive BioMedicine. 2017 Sep;15(9):583.

17. Tejal $P$, Astha D. Relationship of serum uric acid level to maternal and perinatal outcome in patients with hypertensive disorders of pregnancy. Gujarat Medical Journal. 2014;69(2):1-3. 